\title{
Memory Deficits Due to Familial British Dementia BRI2 Mutation Are Caused by Loss of BRI2 Function Rather than Amyloidosis
}

\author{
Robert Tamayev, ${ }^{1 \star}$ Luca Giliberto, ${ }^{1,2 *}$ Wei Li, ${ }^{3}$ Cristina d'Abramo, ${ }^{2}$ Ottavio Arancio, ${ }^{4}$ Ruben Vidal, ${ }^{3}$ \\ and Luciano D'Adamio ${ }^{1}$ \\ ${ }^{1}$ Department of Microbiology and Immunology, Einstein College of Medicine, Bronx, New York 10461, ${ }^{2}$ The Litwin-Zucker Research Center for the Study of \\ Alzheimer's Disease, The Feinstein Institute for Medical Research, North Shore-Long Island Jewish Health System, Manhasset, New York 11030, \\ ${ }^{3}$ Department of Pathology and Laboratory Medicine, the Indiana Alzheimer Disease Center, Indiana University School of Medicine, Indianapolis, Indiana \\ 46202, and ${ }^{4}$ Department of Pathology and Cell Biology, Taub Institute for Research on Alzheimer's Disease and the Aging Brain, Columbia University, New \\ York, New York 10032
}

Familial dementias, which include Alzheimer disease (AD), familial British dementia (FBD), and familial Danish dementia (FDD), are caused by dominantly inherited autosomal mutations and are characterized by the production of amyloidogenic peptides, neurofibrillary tangles (NFTs) and neurodegeneration (St George-Hyslop and Petit, 2005; Garringer et al., 2009). The prevailing pathogenic theory, the "amyloid cascade hypothesis" (Hardy and Selkoe, 2002), posits that the accumulation of amyloidogenic peptides triggers tauopathy, neurodegeneration, and cognitive and behavioral changes. However, this hypothesis is yet to be validated, and causes of dementia may be multifaceted and involve other mechanisms, such as loss of function due to pathogenic mutations. Mouse models of human dementia invariably use transgenic expression systems (LaFerla and Oddo, 2005; McGowan et al., 2006; Vidal et al., 2009; Coomaraswamy et al., 2010) that do not reflect the genotypes of human disease and cannot replicate loss of function. Therefore, we generated a knock-in (KI) mouse model of FBD $\left(\mathrm{FBD}_{\mathrm{KI}}\right)$ genetically congruous with the human disease. FBD is caused by a missense mutation at the stop codon of the $B R I 2$ gene (Vidal et al., 1999 ) and, like $\mathrm{FBD}_{\mathrm{P}}$ patients, $\mathrm{FBD}_{\mathrm{KI}}$ mice carry this mutation in one of the two murine Bri2 alleles. We report that the British mutation drastically reduces expression of mature BRI2 in

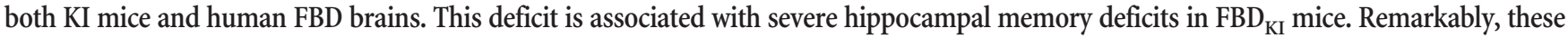
animals showed no cerebral amyloidosis and tauopathy. Bri2 ${ }^{+/-}$mice present memory deficits similar to those in $\mathrm{FBD}_{\mathrm{KI}}$ animals. Collectively, these results indicate that the British BRI2 mutation underlies abnormal memory due to loss of BRI2 function and independently of histopathological alterations typically evident in advanced neurodegenerative disease.

\section{Introduction}

BRI2 is a type II transmembrane protein that belongs to a multigene family comprising BRI1, BRI2 and BRI3 (also referred to as ITM2A, ITM2B and ITM2C, or E25A, E25B and E25C, respec-

Received July 27, 2010; revised Aug. 25, 2010; accepted Aug. 31, 2010.

This work was supported in part by Alzheimer Disease Research Grant A2003-076 (L.D.), National Institutes of Health Grants R01 AG033007 (L.D.) and NS049442 (0.A.), Training Program in Cellular and Molecular Biology and Genetics T32 GM007491 (R.T.), and American Health Assistance Foundation Grant A2008-304 (R.V.). The funders had no role in study design, data collection and analysis, decision to publish, or preparation of the manuscript. We thank Erhan Ma for help in the genotyping and PCR procedures on the $F B_{\mathrm{KI}}$ mice. We thank Dr. Susan Newbigging at the Toronto Centre for Phenogenomics, Toronto, Ontario, Canada. We thank Dr. Bernardino Ghetti for the helpful discussion, Adi Shemesh for helping with LP1 preparations, and Dr. Shuji Matsuda for the Western blot on human brain lysates. We thank Dr. Peter Davies at the Litwin-Zucker Center for the Study of Alzheimer's Disease-Feinstein Institute for Medical Research-North Shore-Long Island Jewish Health System (Manhasset, NY) for providing antiTau antibodies.

The mice discussed in this paper $\left(\mathrm{FBD}_{\mathrm{KI}}\right.$ mice) are patent-pending. The assignee is the Albert Einstein College of Medicine. The Albert Einstein College of Medicine has licensed the patent to a biotech company (Remegenix) of which L.D. is a cofounder.

*R.T. and L.G. have contributed equally.

Correspondence should be addressed to Luciano D'Adamio at the above address. E-mail: luciano.dadamio@einstein.yu.edu.

D0I:10.1523/JNEUROSCI.3917-10.2010

Copyright $\odot 2010$ the authors $\quad 0270-6474 / 10 / 3014915-10 \$ 15.00 / 0$ tively) (Deleersnijder et al., 1996; Pittois et al., 1999; Vidal et al., 1999, 2000, 2001) in both mice and human. It possesses a BRICHOS domain, a conserved motif common to members of the BRI, ChM-I, SP-C and CA11 protein families, thought to have a role in the targeting of proteins to the secretory pathway or to intracellular processing (Sánchez-Pulido et al., 2002). Proteins sharing the BRICHOS motif associate with a diverse range of phenotypes, varying from dementia to cancer and respiratory distress.

BRI2 was originally described in relation to Familial British Dementia (FBD) (Vidal et al., 1999), an autosomal dominant neurodegenerative disease characterized by the early onset of personality changes, memory and cognitive deficits, spastic rigidity, and ataxia. In FBD, a proteolytic C-terminal 34 aa fragment of BRI2, called ABri, accumulates leading to severe amyloid angiopathy of the brain and spinal cord with perivascular amyloid plaque formation, parenchymal plaques affecting the limbic areas, cerebellum cerebral cortex, neurofibrillary degeneration of hippocampal neurons and changes of the periventricular white matter (Plant et al., 1990). A distinct mutation causes a similar autosomal dominant neurodegenerative disorder, Familial Danish Dementia (FDD) (Vidal et al., 2000). BRI2 is physiologically cleaved, at 
the $\mathrm{C}$ terminus, by a proprotein convertase producing a 23 aa soluble C-terminal fragment. In FBD, a single base substitution at the stop codon of BRI2 generates a longer open reading frame, resulting in a larger, 277 aa precursor (compared with the 266 aa normal allele). The outcome of this genetic defect is the generation of the longer amyloidogenic C-terminal fragment ABri (Vidal et al., 1999).

Several neuropathological features are common to FBD, FDD and AD: amyloid deposition neurofibrillary tangles (Holton et al., 2001, 2002; Rostagno et al., 2002), neurodegeneration, and accumulation of complement proteins and their proinflammatory activation products, including $\mathrm{iC} 3 \mathrm{~b}, \mathrm{C} 4 \mathrm{~d}, \mathrm{Bb}$, and C5b-9.

Mouse models are critical to explore both pathogenesis and therapy of human diseases. All animal models used to study human neurodegenerative diseases consist of transgenic mice carrying mutant forms of genes shown to be involved in human dementia (LaFerla and Oddo, 2005; McGowan et al., 2006; Vidal et al., 2009; Coomaraswamy et al., 2010). A serious limitation of these models is that their design is predicated on the assumption that development of amyloid plaques and neurofibrillary tangles is directly related to the cognitive and behavioral changes associated with human dementia. However, this hypothesis is yet to be proven since other mechanisms, such as for example loss of function due to pathogenic mutations could cause or contribute to the pathogenesis of human dementia. Evidence suggests that loss of function could be pathogenic in neurodegenerative diseases. Mutations in PSEN1/PSEN2, which cause familial AD, reduce PSEN1/PSEN2 function (De Strooper, 2007) and deletion of PSEN1/PSEN2 in mouse brains causes neurodegeneration, synaptic dysfunction and memory loss (Saura et al., 2004; Zhang et al., 2009). Since such mechanisms cannot be uncovered by a transgenic approach due to the persistence of the endogenous wild-type (WT) alleles, we generated a genetically coherent KI animal model of FBD, called $\mathrm{FBD}_{\mathrm{KI}}$. The analysis of both anatomical and clinical pathology of $\mathrm{FBD}_{\mathrm{KI}}$ mice questions the validity of the "amyloid cascade hypothesis" and suggests that clinical pathology precedes amyloid and tangles pathology in FBD. Thus, this new mouse model provides a powerful system to gain insights into the molecular basis of human neurodegenerative disorders.

\section{Materials and Methods}

Ethics statement. Mice were maintained on a C57BL/6 background for several generations (at least 15). Mice were handled according to the Ethical Guidelines for Treatment of Laboratory Animals of Albert Einstein College of Medicine. The procedures were described and approved in animal protocol number 20040707. Mice were killed by cervical dislocation after isoflurane anesthesia.

Bri2 knock-in construction. The targeting strategy for the generation of the $\mathrm{FBD}_{\mathrm{KI}}$ mice is similar to that used to generate the $\mathrm{FDD}_{\mathrm{KI}}$ mice (Giliberto et al., 2009) and entails the replacement of the Bri2 exon 6 with a mutated exon 6 carrying the FBD mutation. Differently from the FD$\mathrm{D}_{\mathrm{KI}}$, we produced a $332 \mathrm{bp}$ fragment containing the ABri mutation (t798a substitution, leading to a Stop $\rightarrow \mathrm{R}$ transition at codon 267 and to the introduction of an $\mathrm{XbaI}$ site at nucleotide 799), plus a humanizing substitution $\mathrm{a} \rightarrow \mathrm{g}(\mathrm{acc} \rightarrow \mathrm{gcc}=$ Threonine $\rightarrow$ Alanine $)$ at the 12th codon of exon 6, by serial PCRs, using pBS-Ex3-6 HindIII as a template (Giliberto et al., 2009). Similarly to the $\mathrm{FDD}_{\mathrm{KI}}$ mice, we obtained the construct-Right Arm-LoxP1-PGK-Neomycin cassette-LoxP2-Left Arm-dTA cassette- which was linearized with SalI, purified injected in ES cells strain 129 by electroporation. Selection of the clones in which the construct had integrated properly by homologous recombination was by means of G418 (200 $\mu \mathrm{g} / \mathrm{ml})$, through the Neo cassette, and by means of dTA exclusion. Injection of the two Danish ES cell clones into C57BL/6J blastocysts was performed at the Albert Einstein College of Medicine genetargeting facility, according to the current facility protocol (http://www. aecom.yu.edu/home/SharedFacilities/ViewFacility.asp?ID=30). The sub- sequent PCR analysis on the ES clones and mice, the sequencing, and the Southern blot analysis are similar to the ones described earlier (Giliberto et al., 2009) and yielded similar results. The FBDKI mice studied here consist of two knock-in lines derived from two distinct recombinant ES clones that have given rise to germ-line transmission of the mutation. Therefore the phenotype of the mice cannot be attributable to a specific mutation cosegregating with the British mutation in one ES clone. The targeting vector sequence has been deposited in GenBank with provisory accession number HM357235.

General pathology. After anesthesia, WT and $\mathrm{FBD}_{\mathrm{KI} / \mathrm{KI}}$ animals were perfusion-fixed with $4 \%$ paraformaldehyde in $0.1 \mathrm{M}$ phosphate buffer, pH 7.2 (Sigma), after which brains and organs were removed, embedded in paraffin, and sectioned. Eight micrometer sections were cut and mounted on poly-L-lysine-coated slides. After deparaffination in xylene and rehydration, sections were stained with hematoxylin and eosin (H\&E) and Congo Red by standard methods. Mineralization was visualized in H\&E sections as a deep basophilic amorphous and/or granular material.

Brain histology and immunohistochemistry. Sections from WT and $\mathrm{FBD}_{\mathrm{KI} / \mathrm{KI}}$ animals prepared as above were stained with the H\&E, Congo red, and Thioflavin S (ThS) methods. Immunohistochemical stainings were performed as described previously (Vidal et al., 2009) by using primary antibodies directed against the following antigens: glial fibrillary acidic protein (GFAP) (Dako), ubiquitin (Dako), amyloid $\beta$ protein $(\mathrm{A} \beta)$ clone 4G8 (Signet Laboratories); microtubule-associated protein tau phosphorylated at Ser202/Thr205 (AT8, Pierce Biotechnology, Rockford, IL), keratan sulfate (5D4, Seikagaku Kogyo, Japan), and ABri amyloid peptide (Ab 1705) (Vidal et al., 2009). The sections were counterstained with cresyl violet or H\&E. As control sections from a patient with FBD were run in parallel (kindly provided by Dr. Tamas Revest, University College London, London, UK). For Tau, NeuN and Ibal immunostaining was performed in sections of the olfactory bulb, hippocampus, temporal cortex, brainstem and cerebellum. After rehydration, endogenous peroxidases were quenched with 95\% methanol plus $5 \%$ hydrogen peroxide for $30^{\prime}$. Antigen retrieval was performed with microwave treatment in citrate buffer (10 mu NaCitrate, pH 6.0), 7 min at maximum power plus $7 \mathrm{~min}$ at $60 \%$ power. Nonspecific binding was blocked with $5 \%$ milk-TBS for $1 \mathrm{~h}$ at room temperature. Primary antibodies are as follows: NeuN (Invitrogen \#187373, 1/1000), IbA1 (Wako $\# 019-19741,1 / 1500)$, and nonpurified anti-Tau antibodies DA9 (1/5000), CP13 (1/5000), PHF1 (1/5000), all diluted in 5\% milk-TBS, and left overnight at $4^{\circ} \mathrm{C}$, shaking. Immunostaining was visualized using the avidin-biotin system (Vectastain; Vector Laboratories) and 3,3'diaminobenzidine (Sigma) as the chromogen.

Human and mouse brain, and synaptosome preparations. Brain samples from humans, $\mathrm{FBD}_{\mathrm{KI}}$ mice, and WT littermates were prepared by homogenizing brains (w/v, $10 \mathrm{mg}$ of tissue/100 $\mu \mathrm{l}$ of buffer) in HEPESsucrose buffer (20 mm HEPES/NaOH, pH 7.4, 1 mм EDTA, 1 mM EGTA, $0.25 \mathrm{M}$ sucrose) supplemented with protease and phosphatase inhibitors (PI and $\mathrm{PhI}$ ). The postnuclear supernatant (PNS) was prepared by precipitating the nuclei and debris by centrifuging the homogenates at $1000 \times g$ for $10 \mathrm{~min}$. Twenty micrograms of each PNS were loaded by SDS-PAGE. APP and BRI2 (wild-type and Danish mutants) were detected by 22C11 (Millipore Bioscience Research Reagents, MAB348) or BRI2 antibody (Akiyama et al., 2004). For synaptic preparations, mouse brain was homogenates were centrifuged at $800 \times g$ for $10 \mathrm{~min}$. The supernatant (S1) was separated to supernatant (S2) and pellet (P2) by spinning at $9200 \times g$ for $15 \mathrm{~min}$. P2 was lysed on ice for $30 \mathrm{~min}$ in $\mathrm{H}$ buffer containing $35.6 \mathrm{~mm}$ sucrose. The lysed P2 was separated to supernatant (LS1) and pellet (LP1) by spinning at 25,000 $\times g$ for $20 \mathrm{~min}$. S2 and LS1 were separated to supernatants (S3 and LS2) and pellet (P3 and LP2) by spinning at $165,000 \times g$ for $2 \mathrm{~h}$, respectively. P3 and LP2 were suspended in $\mathrm{H}$ buffer containing $35.6 \mathrm{~mm}$ sucrose by sonication. Synaptosome fractions represent: S1, postnuclear supernatant; S2, cytosol, soluble proteins and light membrane; P2, crude synaptosome fraction; S3, soluble fraction; P3, light membrane abundant in Golgi and ER; LS1, crude synaptic soluble; LP1, synaptic membrane fraction; LS2, synaptic soluble; LP2, synaptic vesicle fraction.

Bain preparation for soluble Tau Western blot. Brain homogenates were sonicated 3 times for $20 \mathrm{~min}$ in ice, spun $20 \mathrm{~min}$ at $20,000 \times g$ at $4^{\circ} \mathrm{C}$, and the supernatant was saved. Tau antibodies were diluted in $5 \%$ dried 
skimmed milk in TBS with $0.1 \%$ Tween 20 and dilutes as follows: DA9 1/1000, CP13 1/2000, PHF1 1/2000, CP9 1/2000.

Tau ELISA. Clear, flat-bottom, 96 well plates were coated overnight with an antibody specific for total Tau (DA31), $2 \mu \mathrm{g} / \mathrm{ml}$ in coating buffer (containing, in mM: $230 \mathrm{~K}_{2} \mathrm{HPO}_{4}, 135 \mathrm{KH}_{2} \mathrm{PO}_{4}, 130 \mathrm{NaCl}, 2$ EDTA, $0.05 \% \mathrm{NaN}_{3}, \mathrm{pH} 7.2$ ). Wells were blocked with $100 \%$ starting block (Pierce) for $1 \mathrm{~h}$ at room temperature. Homogenates were then added: brain homogenates, prepared as described above, were mixed $1 / 1$ with $0.1 \%$ SDS, briefly vortexed, and spun for $10 \mathrm{~min}$ at $20,000 \times g$, at room temperature, and the supernatant was loaded on the ELISA plate at $1 / 250-1 / 2000$ dilution in 20\% Superblock-TBS (Pierce) as needed, and left overnight, at $4^{\circ} \mathrm{C}$, gently shaking. Purified primary antibodies were added to the plate, diluted in 20\% Superblock-TBS, as follows: biotinylated DA9 (IgG1) 1/5000, CP13 (IgG1) 1/500, biotinylated CP17 (IgG3) $1 / 20,000$ and biotinylated PHF1 (IgG1) 1/10,000, and left for $2 \mathrm{~h}$ at room temperature, gently shaking. Secondary antibodies, streptavidin-HRP 1/5000, and HRP-goat anti-mouse IgG1 1/20,000 for CP13 only, were diluted in 20\% Superblock-TBS (Pierce), left on the plate for $1 \mathrm{~h}$ as above. Fifty microliters of TMB (Pierce) were added and left for $20 \mathrm{~min}$, at room temperature, light shielded, gently shaking, and the reaction was stopped with the same volume of $2 \mathrm{M}$ sulfuric acid and read at $450 \mathrm{~nm}$ with an automated Tecan plate reader. Every step was followed by 5 automated washes with washing buffer (100 mm NaCl, $10 \mathrm{~mm}$ Tris base, $0.1 \%$ Tween 20 ).

Spatial working memory. The task studied with the radial arm water maze (RAWM) test has been described previously (Trinchese et al., 2004). Briefly, a six-armed maze was placed into a white tank filled with water $\left(24-25^{\circ} \mathrm{C}\right)$ and made opaque by the addition of nontoxic white paint. Spatial cues were presented on the walls of the testing room. At the end of one of the arms was positioned a clear $10 \mathrm{~cm}$ submerged platform that remained in the same location for every trial in $1 \mathrm{~d}$ but was moved approximately randomly from day to day. On each trial, the mouse started the task from a different randomly chosen arm. Each trial lasted 1 $\mathrm{min}$, and errors were counted each time the mouse entered the wrong arm or needed $>20$ s to reach the platform. After each error, the mouse was pulled back to its starting position. After four consecutive acquisition trials, the mouse was placed in its home cage for $30 \mathrm{~min}$, then returned to the maze and administered a fifth retention trial. The scores for each mouse on the last $3 \mathrm{~d}$ of testing were averaged and used for statistical analysis.

Visible platform testing. Visible platform training to test visual and motor deficits was performed in the same pool as in the RAWM; however, the arms of the maze were removed. The platform was marked with a black flag and positioned randomly from trial to trial. Time to reach the platform and speed were recorded with a video tracking system (HVS 2020; HVS Image).

Open field and novel object recognition. After $30 \mathrm{~min}$ to acclimate to the testing room, each mouse was placed into a $40 \mathrm{~cm} \times 40 \mathrm{~cm}$ open field chamber with 2 feet high opaque walls. Each mouse was allowed to habituate to the normal open field box for $10 \mathrm{~min}$, and repeated again $24 \mathrm{~h}$ later, in which the video tracking system (HVS 2020; HVS Image) quantifies the total distance traveled, number of entries into, and time spent in the center of the locomotor arena. Novel object recognition was performed as previously described (Bevins and Besheer, 2006). Results were recorded as an object discrimination ratio (ODR), which is calculated by dividing the time the mice spent exploring the novel object by the total amount of time exploring the two objects.

Fear conditioning. Our conditioning chamber was in a soundattenuating box. A clear Plexiglas window allowed the experimenter to film the mouse performance with a camera placed on a tripod and connected to the Freeze-frame software (MED Associates). To provide background white noise $(72 \mathrm{~dB})$, a single computer fan was installed in one of the sides of the sound-attenuating chamber. The conditioning chamber had a 36 bar insulated shock grid floor. The floor was removable, and after each experimental subject, we cleaned it with $75 \%$ ethanol and then with water. Mice were handled once a day for $3 \mathrm{~d}$ before behavioral experiments. Only one animal at a time was present in the experimentation room. For the cued and contextual conditioning experiments, mice were placed in the conditioning chamber for $2 \mathrm{~min}$ before the onset of a discrete tone [conditioned stimulus (CS)] (a sound that lasted $30 \mathrm{~s}$ at $2800 \mathrm{~Hz}$ and $85 \mathrm{~dB}$ ). In the last $2 \mathrm{~s}$ of the CS, mice were given a foot shock [unconditioned stimulus (US)] of $0.50 \mathrm{~mA}$ for $2 \mathrm{~s}$ through the bars of the floor, except in an experimental series in which we used $0.75 \mathrm{~mA}$ to elicit more memory. After the CS/US pairing, the mice were left in the conditioning chamber for another $30 \mathrm{~s}$ and were then placed back in their home cages. Freezing behavior, defined as the absence of all movement except for that necessitated by breathing, was scored using the Freezeview software. To evaluate contextual fear learning, freezing was measured for $5 \mathrm{~min}$ (consecutive) in the chamber in which the mice was tested $24 \mathrm{~h}$ after training. To evaluate cued fear learning, after contextual testing, the mice were placed in a novel context (triangular cage with smooth flat floor and with vanilla odorant) for 2 min (pre-CS test), after which they were exposed to the CS for 3 min (CS test), and freezing was measured. Sensory perception of the shock was determined through threshold assessment. A sequence of single foot shocks was delivered to animals placed on the same electrified grid used for fear conditioning. Initially, a $0.1 \mathrm{mV}$ shock was delivered for $1 \mathrm{~s}$, and the animal behavior was evaluated for flinching, jumping, and vocalization. At $30 \mathrm{~s}$ intervals, the shock intensity was increased by $0.1 \mathrm{mV}$ to $0.7 \mathrm{mV}$ and then returned to $0 \mathrm{mV}$ in 0.1 $\mathrm{mV}$ increments at $30 \mathrm{~s}$ intervals. Threshold to vocalization, flinching, and then jumping was quantified for each animal by averaging the shock intensity at which each animal manifests a behavioral response to the foot shock.

Statistical analysis. For mice behavioral studies, all data are shown as mean \pm SEM. Experiments were performed in blind for genotype. Statistical tests included using a Student's $t$ test and a $p<0.05$ was considered significant. For the biochemical studies, all quantified data represent an average of at least triplicate samples. Error bars represent SEM.

\section{Results}

\section{Generation of $\mathrm{FBD}_{\mathrm{KI}}$ mice}

We generated a targeting vector for the introduction of the British mutation in the Bri2 mouse gene. The vector uses the floxed $P G K$-neo selection cassette and contains a 5' homologous region and the negative selection cassette, $P G K-d t$. The $3^{\prime}$ homologous region introduces the $\mathrm{FBD}$ mutation into the Bri2 mouse gene (Fig. 1A). To humanize the mouse $\mathrm{COOH}$-terminal region of Bri2, an alanine was substituted for threonine (T) at codon 250. The linearized targeting vector was transfected into 129 ES cells by electroporation and ES cell clones carrying the proper homologous recombination and the $\mathrm{tABri}$ (targeted ABri) allele were identified by PCR for 5' region (i.e., Left Arm: if homologous recombination had occurred these primers would amplify a product of $\sim 1.67 \mathrm{~kb}$ ) and for the $3^{\prime}$ region (i.e., Right Arm: if homologous recombination had occurred these primers would amplify a product of $\sim 3.4 \mathrm{~kb}$ ). Of the $\sim 600$ screened ES clones, we found 3 clones in which the British mutation was inserted in one of the Bri2 alleles, Bri2 ${ }^{\text {ABri/+ }} 57, B r i 2 t^{A B r i /+} 82$, and Bri2 ${ }^{\text {tABri/+ }}$ 197 as shown in Figure $1 B$. The occurrence of homologous recombination was confirmed by sequencing the PCR products and by performing Southern blot analysis (Fig. 1C). DNA derived from individual Bri2 ${ }^{t A B r i /+}$ ES clones was digested with BamHI, gel separated, blotted into a nylon membrane, and hybridized with either the $5^{\prime}$ or the $3^{\prime}$ probe. The $5^{\prime}$ probe hybridizes with a $\sim 11.9 \mathrm{~kb}$ fragment derived from the wild-type locus. Homologous recombination at the $5^{\prime}$ homologous region yields a $\sim 8.9 \mathrm{~kb}$ fragment upon BamHI digestion due to the introduction of the BamHI site in the PGK-neo selection cassette. ES clones Bri2 ${ }^{t A B r i /+}$ 57, Bri2 $^{\text {tABri/+ }} 82$, and Bri2 ${ }^{\text {tABri/+ }} 197$ carry a wild-type allele (11.9 $\mathrm{kb})$ and a recombined allele $(8.9 \mathrm{~kb})$. The $11.9 \mathrm{~kb}$ and $8.9 \mathrm{~kb}$ bands had a similar intensity, indicating that $50 \%$ of the Bri2 alleles are wild type and 50\% are recombined, and proving that the ES cells we have selected are clonal populations. Similar results were obtained when homologous recombination at the $3^{\prime}$ site was assessed (data not shown). In this case the $3^{\prime}$ probe detected a wild-type $\sim 11.9 \mathrm{~kb}$ fragment and a recombinant $4.7 \mathrm{~kb}$ fragment, due to the introduction of the BamHI site. For subse- 
A

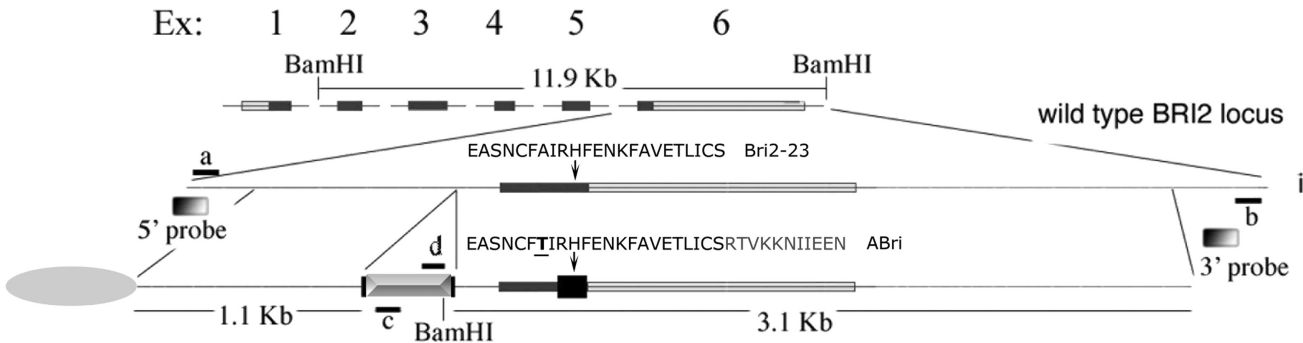

intron 5-exon 6 magnification

Targeting construct

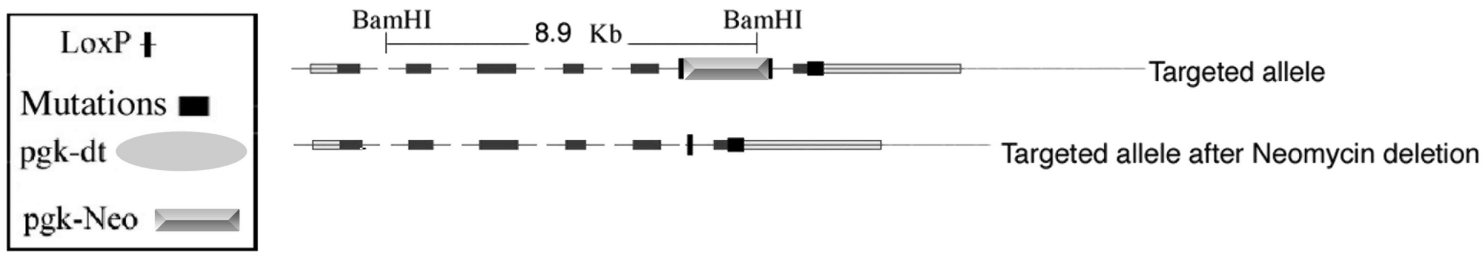

B

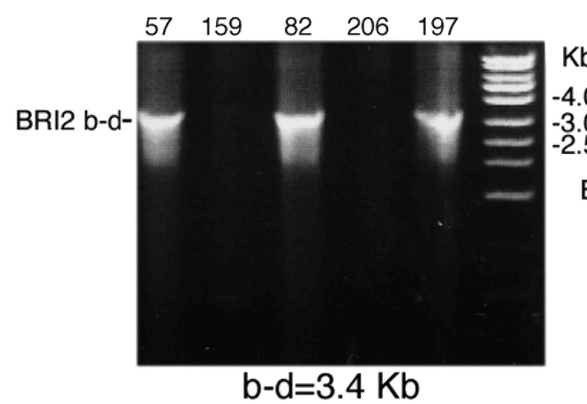

ES BRI2

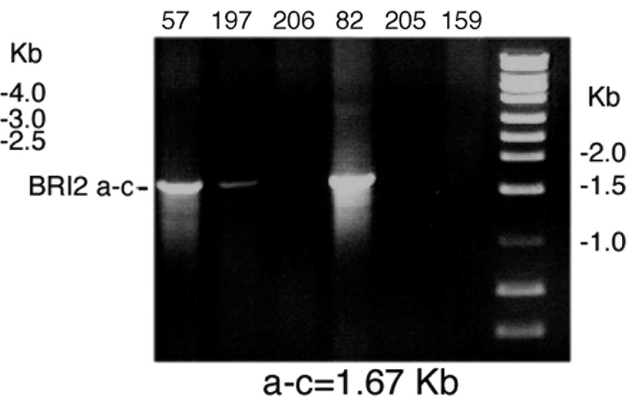

C

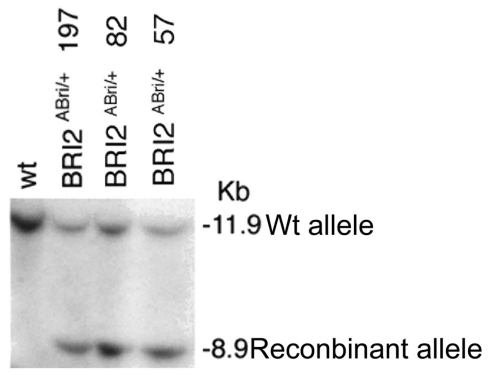

Figure 1. $\mathrm{FBD}_{\mathrm{KI}}$ mouse generation. $A$, Schematic representation of the construct that was injected in $129 \mathrm{ES}$ cells, showing the ABri mutation on Exon 6, primer sites, site of Southern blot probe, LoxP, pgk-dt and pgk-Neo sites. The bottom graphics depict the construct with and without the pgk-Neo cassette that has been removed by means of Cre recombinase. $\boldsymbol{B}$, Examples of 2 ES clones positive for the homologous recombination of the mutated allele: left arm $(\boldsymbol{a}-\boldsymbol{c}: 1.67 \mathrm{~kb})$ and right arm $(\boldsymbol{b}-\boldsymbol{d}, 3.4 \mathrm{~kb})$ PCRs are shown. $\boldsymbol{C}$, Southern blot showing a shift from the $11.9 \mathrm{~kb}$ of the wild-type genome to the $8.9 \mathrm{~kb}$ band of the $\mathrm{FBD}_{\mathrm{Kl}}$ mice, due to the insertion of a new BamHl site. $\mathrm{FBD}_{\mathrm{Kl}}$ mice show both bands, indicating heterozygosity.

quent analysis, only the Bri2 ${ }^{t A B r i /+} 57$ and 82 clones are considered here. These two British ES cell clones (129, agouti coat color), carrying the correct site-specific homologous recombination, were injected into C57BL/6J blastocysts (black coat color). The resulting chimeras with a high proportion of agouti coat color (i.e., with a high relative contribution from the injected ES cells) were backcrossed to C57BL/6J mice to obtain heterozygous $\mathrm{Bri2}^{t A B r i / w t}$, which were identified by PCR and Southern analysis as described above (data not shown) using tail DNA. The Neo cassette was deleted by crossing Bri2 ${ }^{t A B r i / w t}$ mice to Meu40-Cre mice. In this article we will use $\mathrm{FBD}_{\mathrm{KI}}$ to indicate mice that have, like the human patients, one WT Bri2 allele and a mutant one, and $\mathrm{FBD}_{\mathrm{KI} / \mathrm{KI}}$ to indicate mice with both Bri2 alleles mutated.

General characteristics and pathology of the $\mathrm{FBD}_{\mathrm{KI} / \mathrm{KI}}$ mice Mice presented with no growth abnormalities and thrived at appropriate age, as their wild-type littermates. Animals were active and alert, and they presented in good body condition with adequate body fat. Overall, these mice have lesions that are commonly found in older mice and are considered age-related, spontaneous lesions and are within the normal limits for age-related lesions.

$\mathrm{FBD}_{\mathrm{KI} / \mathrm{KI}}$ mice do not present FBD-related neuropathology Brain sections of 18-month-old mice were first examined for FBD-related pathology. For comparison, we included sections of a patient with FBD (Holton et al., 2001). No staining of vascular amyloid, plaques, or diffuse deposits was observed in knock-in mice by ThS (Fig. $2 A$ ) or by using the anti-ABri antibody 1705 (Fig. 2C). An affected blood vessel from an FBD patient stained with ThS (Fig. 2B) and immunostained with antibody 1705 (Fig. $2 D$ ) are shown for comparison. Immunostaining using antiGFAP antibodies did not reveal significant differences between WT mice (Fig. $2 F$ ) and $\mathrm{FBD}_{\mathrm{KI} / \mathrm{KI}}$ mice (Fig. $2 G$ ) in activated astrocytes. No significant differences between $\mathrm{WT}$ and $\mathrm{FBD}_{\mathrm{KI} / \mathrm{KI}}$ were observed after staining with antibody 5D4 (data not shown) and IbA1 (Fig. $2 G, \mathrm{FBD}_{\mathrm{KI} / \mathrm{KI}}$; H, WT; hippocampi shown) for the detection of activated microglia. When searching for clues of neuronal loss, we did not find any weakening of NeuN signal, as shown in samples form hippocampi of $\mathrm{FBD}_{\mathrm{KI} / \mathrm{KI}}$ (Fig. $2 I, K$ ) compared with control (Fig. $2 J, L$ ) mice. $\mathrm{H} \& \mathrm{E}$ staining of $\mathrm{FBD}_{\mathrm{KI} / \mathrm{KI}}$ mice showed no significant loss of neurons or noticeable malformations compared with WT littermates. These results indicated that the brain of $\mathrm{FBD}_{\mathrm{KI} / \mathrm{KI}}$ mice maintained normal morphology of aged mice and were free of ABri deposits at 18 months of age.

Tau pathology, i.e., hyperphosphorylation and tangle formation, is a known characteristic of BRI2-associated dementias (Vidal et al., 1999, 2000) and generally correlates better than amyloid deposition with cognitive deficits in dementias. Thus, we investigated whether FBD mice bear such features.

Immunostaining of 18 -month-old $\mathrm{FBD}_{\mathrm{KI} / \mathrm{KI}}$ and control mice with a total Tau antibody (DA9) showed a neuronal cytoplasmic staining in most areas of the brain, including the cerebellum and brainstem (data not shown), hippocampus (Fig. $3 A, \mathrm{FBD}_{\mathrm{KI} / \mathrm{KI}} ; B$, $\mathrm{WT}$ ) and temporal subcortical region (Fig. $3 C, \mathrm{FBD}_{\mathrm{KI} / \mathrm{KI}} D, \mathrm{WT}$ ). 

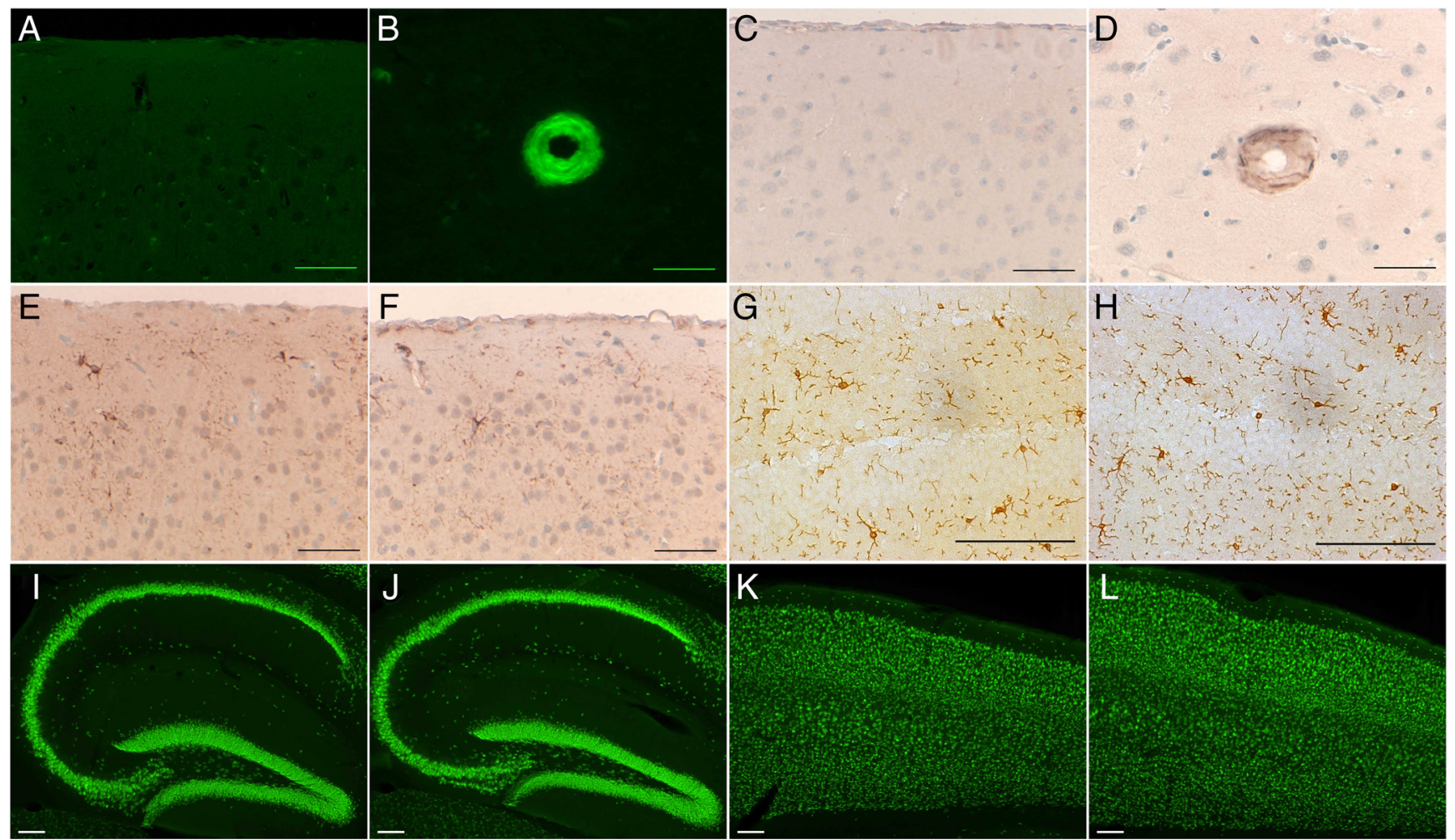

Figure 2. FBD mice have neither amyloid lesions nor inflammatory response. $\boldsymbol{A}-\boldsymbol{F}$, Sections from a $F B D_{K I / K l}$ mouse $(\boldsymbol{A}, \boldsymbol{C}, \boldsymbol{E})$, a WT mouse $(\boldsymbol{F})$, and a patient with $F B D(B, D)$, were stained with ThS $(\boldsymbol{A}, \boldsymbol{B})$, Ab 1705 , specific for the ABri amyloid peptide $(\boldsymbol{C}, \boldsymbol{D})$ and anti-GFAP $(\boldsymbol{E}, \boldsymbol{F})$. No significant differences were observed between WT and knock-in mice. $\boldsymbol{G}, \boldsymbol{H}$, Iba1 staining is also similar in hippocampi of FBD $(\boldsymbol{G})$ and control $(\boldsymbol{H})$ mice, as well in the other areas (cerebellum, cortices, brainstem and olfactory bulb: not shown). Scale bars, $50 \mu \mathrm{m}$. $\boldsymbol{I}-\boldsymbol{L}$, NeuN staining shows similar cellularity

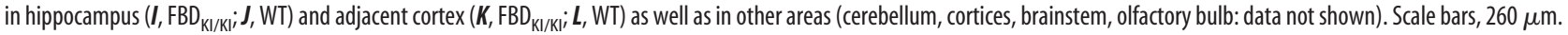

No difference was observed between $\mathrm{FBD}_{\mathrm{KI} / \mathrm{KI}}$ and control mice. The staining with CP13, an antibody that recognize the "early" Tau phosphorylation site Ser 202, was similar to that seen with DA9 in the hippocampus (Fig. $3 E, \mathrm{FBD}_{\mathrm{KI} / \mathrm{KI}} ; F, \mathrm{WT}$ ) and entorhinal cortex (Fig. $G, \mathrm{FBD}_{\mathrm{KI} / \mathrm{KI}}$; $H, \mathrm{WT}$ ) and other areas (cerebellum, olfactory bulb, brainstem: not shown). No axonal staining was observed and no significant difference was noted between $\mathrm{FBD}_{\mathrm{KI} / \mathrm{KI}}$ and control mice.

PHF1 antibody ("late" Ser396/404 phosphorylation) showed a more marked staining of neurons, and possibly oligodendrocytes, with more axonal involvement, with a similar pattern in both $\mathrm{FBD}_{\mathrm{KI} / \mathrm{KI}}$ and controls (Fig. 3I, J, hippocampus of $\mathrm{FBD}_{\mathrm{KI} / \mathrm{KI}}$ and $\mathrm{WT}$ respectively; $K, L$, temporal cortical and subcortical area of $\mathrm{FBD}_{\mathrm{KI} / \mathrm{KI}}$ and Wt respectively; cerebellum, brainstem and olfactory bulb not shown). No significant differences were observed using commercially available antibody AT8 (data not shown).

Biochemical analysis of Tau accumulation and phosphorylation was performed by means of ELISA (Fig. 3M) and Western blot (Fig. $3 N$ ) on 6-month-old $\mathrm{FBD}_{\mathrm{KI}}$ mice. Total Tau (DA9), pSer202Tau (CP13), pThr231Tau (CP17 and CP9), and pSer396/404Tau (PHF1) were not different in the 4 analyzed FBDKI mice compared with 4 littermates. Altogether, these data point toward a normal "aging" pattern, as far as Tau and its modifications are concerned in FBDKI/KI and FBDKI mice, similar to what is seen in WT littermates.

Levels of BRI2 protein are reduced in human FBD brains and in synapses of $F B D_{K I}$ mice

Analysis of normal human brain samples and a sample from an FBD patient (kindly provided by Dr. Jorge Ghiso, New York University School of Medicine, New York, NY) showed reduced BRI2 levels in the British dementia case (Fig. 4A). Next, we studied $\mathrm{FBD}_{\mathrm{KI}}$ mice, which faithfully reproduce the genetic defect of FBD patients since they carry one allele coding for WT Bri2 and the other coding for Bri2-ABri. In $\mathrm{FBD}_{\mathrm{KI}}$ mice, mBri2 levels were dramatically reduced, similar to what is seen in human brains (Fig. 4B). Quantification of the triplicate data indicates that the reductions are significant $(\mathrm{S} 1, p=0.0059$; $\mathrm{LP} 1, p=$ $0.0024)$, These differences are not due to defective transcription/ splicing of the mutant allele since $\sim 50 \%$ of the Bri2 mRNA coded for the mutant protein in the $\mathrm{FBD}_{\mathrm{KI}}$ brains (data not shown). These data indicate that the FBD mutation compromises formation of mBRI2 in vivo. It will be important to analyze the biochemical mechanism by which the British mutation causes a reduction in $\mathrm{mBR} 2$ level. Preliminary data suggest that the mutation affects trafficking of the mutant protein out of the endoplasmic reticulum and may target the protein for degradation.

Loss of memory is a clinical hallmark of FBD, and Ramon y Cajal (1911) predicted that dementia results from the weakening of synapses. We have, therefore, investigated whether Bri2 is expressed in synaptic termini. Interestingly, we found that while Bri2 is enriched in synaptic membranes in WT mice (LP1, Fig. $4 C$ ), Bri2 is substantially reduced in synaptic membranes isolated from $\mathrm{FBD}_{\mathrm{KI}}$ mice (Fig. $4 D$ ).

\section{$F B D_{K I}$ mice present memory deficits}

Although $\mathrm{FBD}_{\mathrm{KI}}$ mice do not present neuropathological lesions, the reduction in $\mathrm{mBri} 2$ protein found in synaptic preparation of $\mathrm{FBD}_{\mathrm{KI}}$ animals prompted us to examine whether $\mathrm{FBD}_{\mathrm{KI}}$ mice presented signs of cognitive impairments by testing behavior and memory. Since the genetic background heavily influences behavioral tests, $\mathrm{FBD}_{\mathrm{KI}}$ mice were backcrossed to $\mathrm{C} 57 \mathrm{BL} / 6 \mathrm{~J}$ mice for 15 

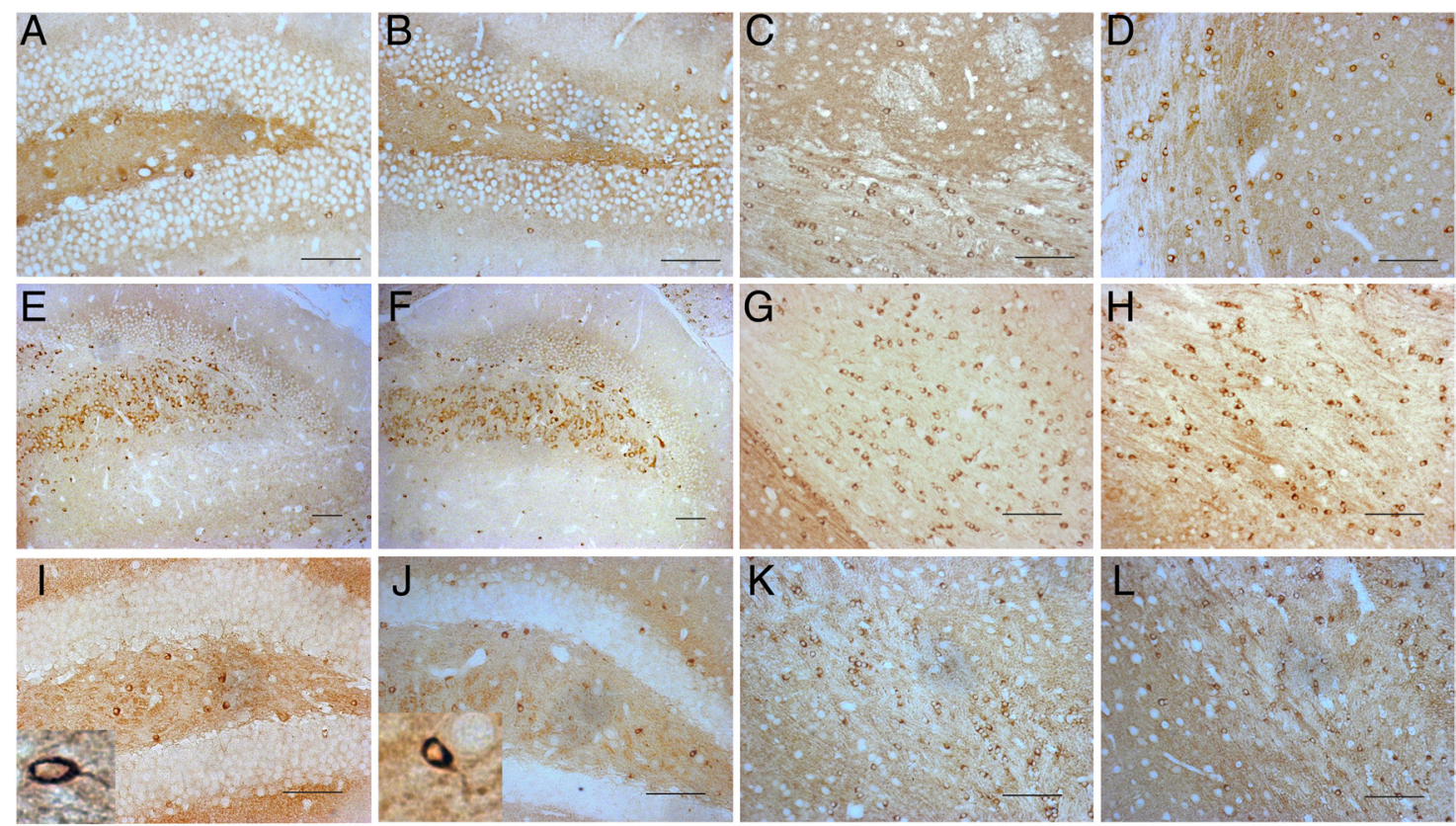

$\mathrm{M}$

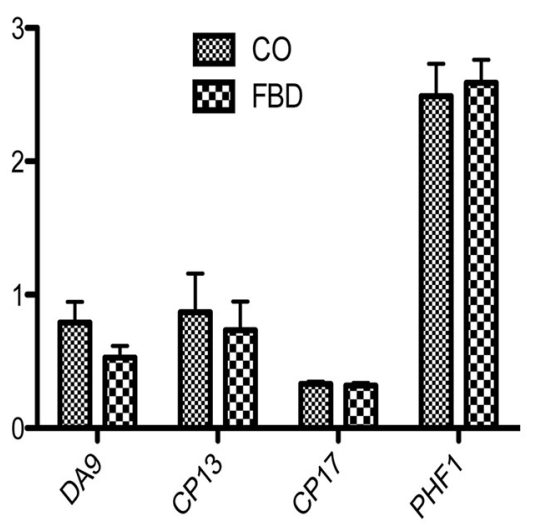

$\mathrm{N}$
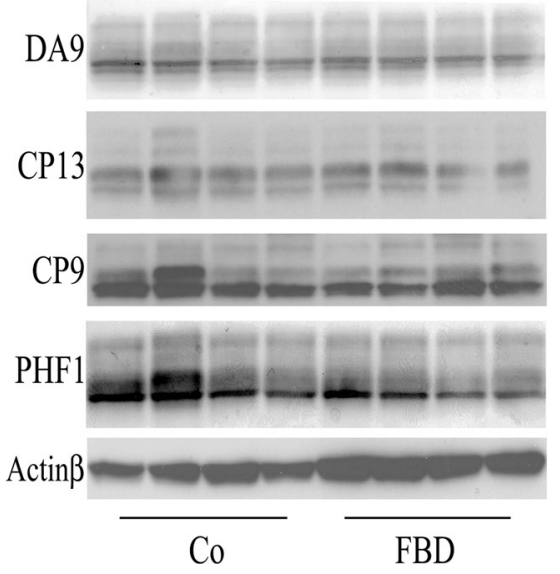

Figure 3. FBD mice do not present tauopathy. $\boldsymbol{A}-\boldsymbol{D}$, Hippocampal sections of $\mathrm{FBD}_{\mathrm{KI} / \mathrm{Kl}}$ mice $(\boldsymbol{A})$ show intracellular DA9 (total Tau) staining similar to control mice $(\boldsymbol{B})$. $F B D_{\mathrm{KI} / \mathrm{Kl}}(\boldsymbol{C})$ and control mice (D) also show similar Tau immunoreactivity in gray and white matter of the temporal lobe. $\boldsymbol{E}, \boldsymbol{F}$, Hippocampi of $\mathrm{FBD}_{\mathrm{KI} / \mathrm{Kl}}$ mice $(\boldsymbol{E})$ and control mice $(\boldsymbol{F})$ show $(\mathrm{P} 13$ cytoplasmic staining, with some neurons showing initial neuritic involvement, without significant difference between the knock-in and the WT animals. $\mathbf{G}-\boldsymbol{L}$, Similarly, the entorhinal cortex $\left(\mathbf{G}, F B D_{K / / K} ; \boldsymbol{H}, W T\right)$ shows $(P 13$ immunostaining, with no difference between the genotypes. PHF staining was not different in $\mathrm{FBD}_{\mathrm{KI} / \mathrm{Kl}}$ and control mice in the hippocampus $\left(\boldsymbol{I}, \mathrm{FBD} \mathrm{KI/Ki}_{\boldsymbol{l}} \boldsymbol{J}, \mathrm{WT}\right)$ with rare neuritc staining (insets), in the temporal cortical and subcortical region ( $\boldsymbol{K}, \mathrm{FBD} \mathrm{KI}_{\mathrm{K} / \mathrm{Ki}} \boldsymbol{L}$, WT). Scale bars: $\boldsymbol{A}-\boldsymbol{L}, 50 \mu \mathrm{m}$. $\boldsymbol{M}$, Quantification of total Tau (DA9) and of 3 Tau phosphorylation sites (CP13: pSer202; (P17: pThr231; PHF1: pSer396/Ser404) by sandwich ELISA shows no significant difference in whole forebrains from $\mathrm{FBD}_{\mathrm{KI}}$ and control mice at 24 months of age. $\boldsymbol{N}$, Western blot analysis of $4 \mathrm{FBD}_{\mathrm{KI}}$ mice and 4 control littermates, at 6 months, fails to show differences in total Tau and 3 phosphorylation sites (CP13: pSer202; (P9: pThr231; PHF1: pSer396/Ser404) in these mice.

generations before performing behavioral tests. In addition, only male mice were used to avoid problems due to menstrual cyclerelated hormonal changes in females. Open field is a sensorimotor test for locomotor, habituation, exploratory, and emotional behavior, including risk assessment and anxiety-like behavior, in novel environments. The number of entries into the center and time spent in the center are indicators of anxiety levels. The more the mouse enters the center and explores it, the lower the level of anxiety-like behavior. Since the $\mathrm{FBD}_{\mathrm{KI}}$ mice are similar to the WT mice $(p=0.83$ for number of entries into the center, and $p=$ 0.67 for the time spent in the center), there is no deficit or excess of anxiety. Due to the similar total track lengths $(p=0.94)$ the $\mathrm{FBD}_{\mathrm{KI}}$ mice have no deficit in locomotor behavior and habituation. These defects would have prevented us from performing memory tests on these animals. Following the open field test, the same bin was used to put the $\mathrm{FBD}_{\mathrm{KI}}$ and WT mice through a novel object recognition (NOR) behavior test to begin assessing mem- ory. NOR is a nonaversive task that relies on the mouse's natural exploratory behavior. During the training session, both the $\mathrm{FBD}_{\mathrm{KI}}$ and WT mice spent the same amount of time exploring the two identical novel objects (Fig. $5 \mathrm{~A}$ ). The following day, when a novel object was introduced, the $\mathrm{FBD}_{\mathrm{KI}}$ mice still spent the same amount of time exploring the two objects as if they were both novel to them, while the WT mice spent more time exploring the novel object compared with the object used $24 \mathrm{~h}$ prior, as expected (Fig. $5 B$ ). This finding indicate that memory is impaired in $\mathrm{FBD}_{\mathrm{KI}}$ mice in an ethologically relevant, nonaversive behavioral context.

Next, we tested whether the mice had any deficits that would prevent them from completing a spatial working memory test such as the radial-arm water maze (RAWM) test, which depends upon hippocampal function (Diamond et al., 1999). Testing with the visible platform showed no difference in the time needed to find the platform and swimming speed 

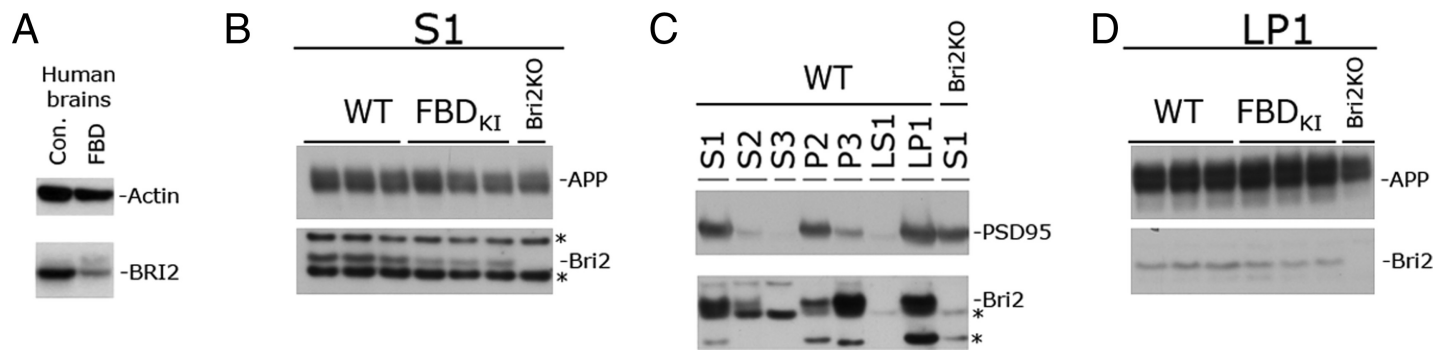

Figure 4. Mature $\mathrm{BRI} 2$ levels are reduced in $\mathrm{FBD}_{\mathrm{KI}}$ mice and in human $\mathrm{FBD}$. $A$, Lysates from a control and an $\mathrm{FBD}$ case were blotted with antibodies against Bri2 and actin. Mature $\mathrm{BRI} 2$ is reduced the $F B D$ brain. $\boldsymbol{B}, \operatorname{In} \mathrm{FBD}_{\mathrm{KI}}$ mice, Bri2 is reduced in total brain lysates (S1). C, Bri2 is enriched in synaptic membranes (LP1) in WT animals. D, However synaptic levels of Bri2 (LP1) are reduced in FBD ${ }_{\mathrm{KI}}$ mice. ${ }^{*}$ indicates nonspecific bands also present in BrizKO (Bri2 ${ }^{-1-}$ ) mice (Matsuda et al., 2008).
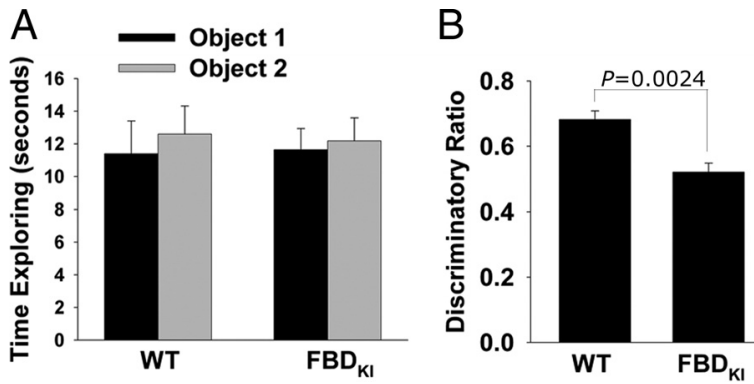

Figure 5. Memory is impaired in $\mathrm{FBD}_{\mathrm{KL}}$ mice in an ethologically relevant, nonaversive behavioral context. $A$, Ten-month-old $\mathrm{FBD}_{\mathrm{Kl}}$ and WT animals spent the same amount of time exploring the two identical novel objects. $\boldsymbol{B}$, Twenty-four hours later, $\mathrm{FBD}_{\mathrm{Kl}}$ mice do not recognize the new object, while the WT mice do.

between the two groups $\left[\mathrm{FBD}_{\mathrm{KI}}\right.$ and $\mathrm{WT}$ mice have similar speed $(p=0.19)$ and need similar time $(p=0.98)$ to reach a visible platform at the age tested] and found that there were no deficits in vision, motor coordination, or motivation in the $\mathrm{FBD}_{\mathrm{KI}}$ mice compared with WT littermates. In the RAWM, mice are required to learn and memorize the location of a hidden platform in one of the arms of a maze with respect to spatial cues. WT mice were able to acquire (A) and retain (R) memory of the task. Striking differences were seen with 9-month-old $\mathrm{FBD}_{\mathrm{KI}}$ mice, which showed severe abnormalities during acquisition, A3 $(p=0.027)$ and A4 $(p=0.0089)$ and retention of the task $(p<0.0001)$ (Fig. 6). The differences were not due to impairment of speed or vision, as stated above, indicating that $\mathrm{FBD}_{\mathrm{KI}}$ mice have severe impairment in spatial memory for platform location during both acquisition and retention of the task.

We used another test of hippocampus-dependent memory: fear-conditioning learning. The fear-conditioning learning paradigm depends on the hippocampus and amygdala. The hippocampus, in particular, is indispensable for contextual fear conditioning (Phillips and LeDoux, 1992), a form of associative learning in which mice must associate a neutral stimulus with an aversive one. This type of cognitive test is more rapid than other behavioral tasks that require multiple days of training and testing. In a series of preliminary experiments, we tested whether the $\mathrm{FBD}_{\mathrm{KI}}$ and WT mice had different perceptions of an electric shock. We found that the shock threshold was the same for mice of the different genotypes (data not shown). Next we examined contextual fear conditioning. $\mathrm{FBD}_{\mathrm{KI}}$ and WT littermates 9 months of age were subjected to a standard fear-conditioning paradigm (Bourtchuladze et al., 1994). The animals were placed in a novel context (fear-conditioning box) and were exposed to a tone (conditioned stimulus [CS]) paired with a mild foot shock

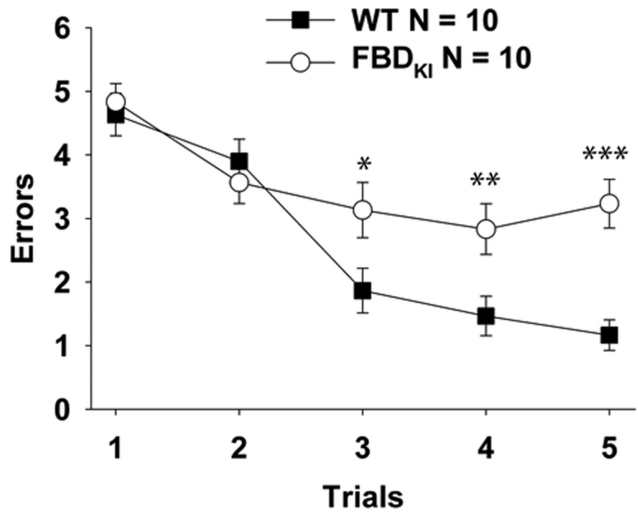

Figure 6. Short-term memory is impaired in $\mathrm{FBD}_{\mathrm{Kl}}$ mice. $\mathrm{FBD}_{\mathrm{K} 1}$ mice present spatial working memory deficits at 9 months of age. $\mathrm{FBD}_{\mathrm{KI}}$ mice do not learn the position of the hidden platform compared with WT littermates [FBD ${ }_{\mathrm{KI}}: n=10$ males; WT: $n=10$ males; no difference was found at $\mathrm{A} 1$ ( $p=0.65$ ) and $\mathrm{A} 2$ (0.49); however, a significant difference was seen at $\mathrm{A} 3$ ( $p=$ $0.027)$, at A4 $(p=0.0089)$, and the retention trail (R) $(p<0.0001) .{ }^{*} p<0.05,{ }^{* *} p<0.01$, ${ }^{* * *} p<0.0001$

(unconditioned stimulus [US]) (training phase of the fear conditioning). Conditioning was assessed $24 \mathrm{~h}$ later by measuring "freezing" behavior - the absence of all movement except for that necessitated by breathing - in response to the context (contextual conditioning) or the auditory cue (CS) within a completely different context (cued conditioning). During the training phase, we found no difference in the freezing of $\mathrm{FBD}_{\mathrm{KI}}$ and WT littermates mice (Fig. 7A). A Student's $t$ test revealed no significant difference between the 2 groups ( $p=0.19$ ). Twenty-four hours later we found a decrease in the freezing time of $\mathrm{FBD}_{\mathrm{KI}}$ mice compared with that of WT littermates in contextual conditioning (Fig. 7A). We next tested cued fear conditioning, a hippocampusindependent task (Phillips and LeDoux, 1992), and did not find a difference in freezing behavior between the 2 groups (Fig. $7 B$ ). This result suggests that the amygdala, which is involved mainly in cued conditioning, is not impaired in these mice. These findings indicate that $\mathrm{FBD}_{\mathrm{KI}}$ mice have a selective hippocampusdependent impairment in associative learning. Altogether these data show that depletion of Bri2 is associated with impaired memory in $\mathrm{FBD}_{\mathrm{KI}}$ mice.

Reduction of Bri2 levels results into cognitive loss similar to that seen in $\mathrm{FBD}_{\mathrm{KI}}$ mice. The data show that memory deficits in $\mathrm{FBD}_{\mathrm{KI}}$ mice correlate with depletion of $\mathrm{mBri} 2$ from synapses rather than cerebral amyloidosis and tauopathy, suggesting that clinical dementia occurs independently of pathological lesions in FDD and via loss of function mechanisms. To further test the hypothesis that British dementia is caused by loss of BRI2 function, we analyzed Bri2 haplodeficient mice 
(Matsuda et al., 2008). These mice express reduced mBri2 levels and do not produce any ABri peptide. Notably, Bri2 ${ }^{+/-}$ animals show memory impairments similar to $\mathrm{FBD}_{\mathrm{KI}}$ mice (Fig. $8 A-D$ ), further suggesting that loss of Bri2 function rather than the ABri peptide causes memory deficits in $\mathrm{FBD}_{\mathrm{KI}}$ mice. Western blot analysis confirms that the synaptic levels of $\mathrm{mBri} 2$ are reduced in Bri2 haplodeficient mice (Fig. $8 E$ ). Quantification of the data indicate that, if an arbitrary value of 100 is assigned to protein levels in WT samples, the values of Bri2 are $100 \pm 3.27$ for the WT vs $39.28 \pm 9.09$ for the Bri $2^{+/-}$ samples $(p=0.0033)$. APP levels are instead similar in the two genotypes $(p=0.73)$.

\section{Discussion}

In this manuscript we characterize a KI model for FBD. Mouse models for human dementias are conventionally based on a transgenic approach in which human mutant proteins that cause familial forms of dementia are overexpressed under the control of brainspecific promoters (Price et al., 2000; LaFerla and Oddo, 2005; McGowan et al., 2006). The transgenic approach is predicated on the amyloid cascade hypothesis, which deems essential the reproduction of cerebral amyloidosis when modeling dementia in mice. Transgenic models are, however, genetically un-congruous with the human diseases and, in addition, the mutant transgene is expressed in an artificial quantitative-spatio-temporal manner. On the contrary, in the KI mice, the pathogenic human mutation is inserted in the mouse allele, and KI models are genetically faithful to the human pathology. However, the KI model does not successfully reproduce in mice the neuropathological lesions observed in humans affected by the disease.

This limitation is critical if development of amyloid plaques and neurofibrillary tangles is directly related to the cognitive and behavioral changes associated with human dementia (Hardy and Selkoe, 2002; St George-Hyslop and Petit, 2005; Garringer et al., 2009). Analyzing memory in the $\mathrm{FBD}_{\mathrm{KI}}$ model, which does not present any detectable neuropatho-

logical lesions such as cerebral amyloidosis and tauopathy, allows us to directly test this hypothesis. Our results quite strikingly show that $\mathrm{FBD}_{\mathrm{KI}}$ mice present severe memory impairments already at 9 months of age. We tested hippocampus-dependent memory using 2 different assays: spatial working memory and fear-conditioning learning. Examination of spatial working memory, a type of short-term memory that can be studied with the RAWM test, showed significant deficits in $\mathrm{FBD}_{\mathrm{KI}}$ mice, both in the acquisition and retention phase of the task. Notably, shortterm memory is affected at early stages in AD (Welsh et al., 1991, 1992). BBD $_{\mathrm{KI}}$ mice also have a selective hippocampus-dependent impairment in associative learning. Interestingly, the amygdala, which is involved mainly in cued conditioning, is not impaired in these mice. $\mathrm{FBD}_{\mathrm{KI}}$ and WT mice were also subjected to a novel object recognition behavior, which assesses a different type of memory. NOR is a nonaversive task that relies on the mouse
A
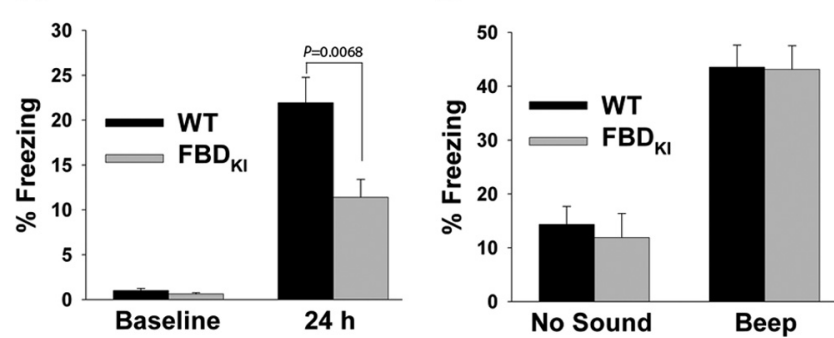

Figure 7. Contextual fear-conditioning deficits in 9-month-old $\mathrm{FBD}_{\mathrm{KI}}$ mice. $A, \mathrm{FBD}_{\mathrm{KI}}$ and WT littermates show no difference in freezing during training (baseline; $p=0.19$ ), whereas contextual fear conditioning performed $24 \mathrm{~h}$ after training shows a reduction of freezing responses in $\mathrm{FBD}_{\mathrm{KI}}$ mice compared with WT littermates [the freezing time of $\mathrm{FBD}_{\mathrm{KI}}$ mice was $\sim 50 \%$ of WT mice; $n=10$ males, WT littermates, $n=10$ males $(p=0.0068)$. $\boldsymbol{B}$, Nine-month-old $\mathrm{FBD}_{\mathrm{KI}}$ mice and WT littermates show similar freezing during cued conditioning, both in the pre-CS group (no sound, $p=0.67$ ), and in the (S group (Sound, $p=0.95$ ).
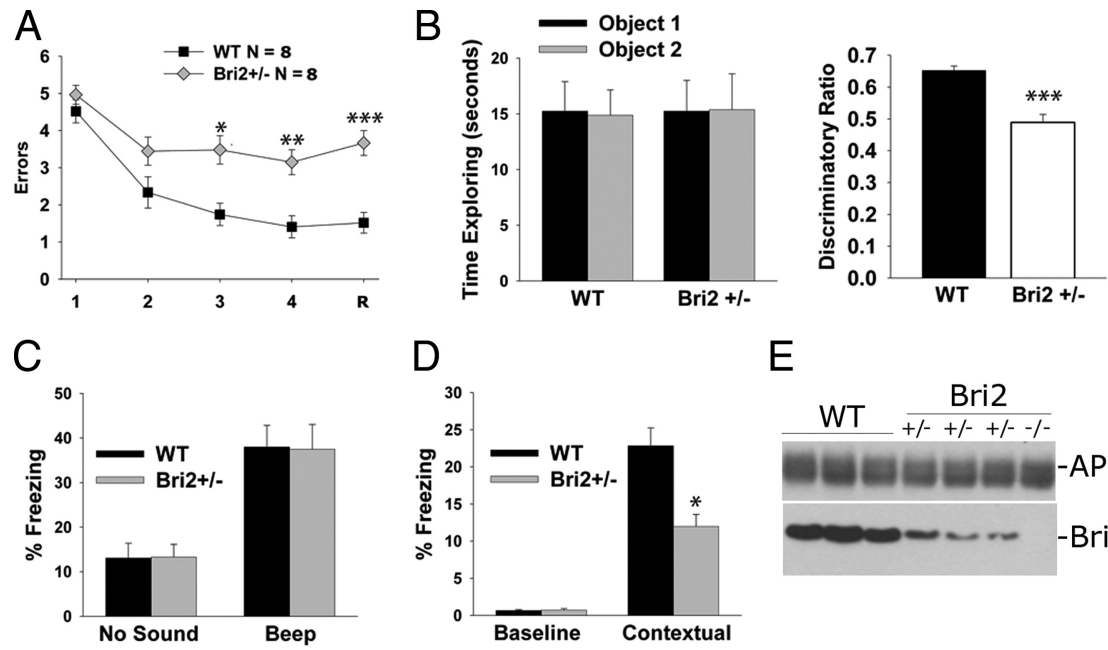

D

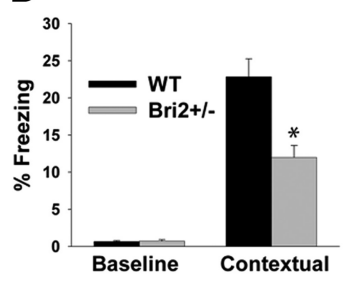

E

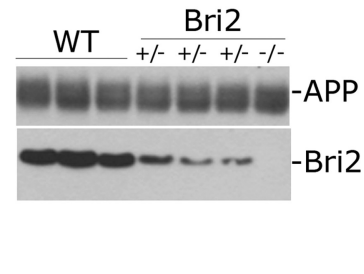

Figure 8. Bri2 ${ }^{+/-}$mice present cognition deficits similar to those of $\mathrm{FBD}_{\mathrm{KI}}$ mice. $A$, Seven-month-old Bri2 ${ }^{+/-}$mice present spatial working memory deficits [no difference was found at $A 1(p=0.58)$ and $A 2(0.076)$, however, a significant difference was in the pre-CS group, $p=0.96$, and in the $(S$ group, $p=0.94)$. $D, B r i 2^{+/-}$and WT littermates show no difference in freezing (baseline; $p=0.8$ ), whereas contextual fear conditioning performed $24 \mathrm{~h}$ after training shows a reduction of mice compared with WT littermates [the freezing time of Bri2 ${ }^{+}-$mice was $\sim 50 \%$ of WT mice; $n=8$ males, WT littermates, $n=8$ males $(p=0.0021)$. ${ }^{*} p<0.002 ;{ }^{* *} p<0.001$; ${ }^{* * *} p<0.0001$. $E$, Bri2 levels are reduced in synaptic fractions (LP1) of Bri2 ${ }^{+/-}$mice compared with littermates. The absence of the signal in Bri2 ${ }^{-1-}$ mice attests the specificity of the band. Levels of APP are comparable in all genotypes.

natural exploratory behavior and showed that memory is impaired in $\mathrm{FBD}_{\mathrm{KI}}$ mice in an ethologically relevant, nonaversive behavioral context. Remarkably, these memory deficits are associated with depletion in $\mathrm{mBri} 2$ protein levels in $\mathrm{FBD}_{\mathrm{KI}}$ mice. This reduction in $\mathrm{mBri} 2$ is not an artifact of the mouse system since brain from a human FBD case shows a similar mBRI2 lowering. Remarkably, Bri2 ${ }^{+/-}$mice show cognition defects similar to those seen in $\mathrm{FBD}_{\mathrm{KI}}$ mice. Bri2 ${ }^{+/-}$mice present deficits in spatial working memory, explorative memory and associative learning, while the amygdala is not impaired. Altogether, the data are consistent with the supposition that loss of function (Saura et al., 2004; De Strooper et al., 2007) plays a prominent role in the pathogenesis of FBD, even though we cannot exclude that untraceable amounts of neurotoxic ABri peptides could contribute to the pathology. Interestingly, the $\mathrm{FDD}_{\mathrm{KI}}$ mice that we have developed (Giliberto et al., 2009), present memory deficits 
at as early as 6 months of age (Tamayev et al., 2010), although the mice have no cerebral amyloidosis, tauopathy and reactive glyosis even at 18 months of age.

Vidal et al. (2009) have previously described a transgenic mouse overexpressing the Danish BRI2 mutant, called tg-FDD, characterized by the presence of widespread cerebral amyloid angiopathy and parenchymal amyloid deposition of ADan peptide. Given the presence of defects in locomotor behavior, the authors could not however analyze cognition and memory in tg-FDD mice. More recently, another FDD transgenic model with ADan deposition (called ADanPP-Tg mice) has been described (Coomaraswamy et al., 2010). Notably, ADanPP-Tg mice failed to develop mixed $\mathrm{ADan} / \mathrm{A} \beta$ plaques, which are the type of lesions present in FDD patients (Vidal et al., 2000), even when crossed to $\mathrm{A} \beta$-depositing mice. On the contrary, the Danish BRI2 mutant strongly reduced $\mathrm{A} \beta$ plaques in double transgenic mice, similarly to what previously shown for wild-type BRI2 (Kim et al., 2008; Matsuda et al., 2008). These data indicate that the amyloid lesion in ADanPP-Tg mice are different from those present in FDD patients and confirm an inhibitory effect of $\mathrm{BRI} 2$ on $\mathrm{A} \beta$ production (Matsuda et al., 2008). ADanPP-Tg mice do not show cognitive and memory defects in the first 12 months of life despite considerable amyloid load. At older ages, ADanPP-Tg mice show deficits with the cue navigation task of the Morris water maze associated with increase of thigmotaxis and passive floating, lower speed, less body weight and an anxiety-related phenotype. These anomalies make assessment of cognition and memory in old ADanPP-Tg mice not doable (Coomaraswamy et al., 2010).

The $\mathrm{FBD}_{\mathrm{KI}}$ mice must produce the ABri peptide, as indicated by the fact that a small fraction of mutant Bri2 undergoes maturation in mice with two mutant copies of the Itm $2 b / B r i 2$ gene (data not shown). Even if our results suggest that ABri does not cause memory deficits, it is possible that ABri may set off other clinical symptoms of FBD patients, such as progressive ataxia, that are not replicated in $\mathrm{FBD}_{\mathrm{KI}}$ mice.

The synaptic function(s) of mBri2 will have to be clarified and whether deregulation of this function(s) cause synaptic plasticity and memory deficits in $\mathrm{FBD}_{\mathrm{KI}}$ mice will need further investigation. Several recent papers have established an interesting link between BRI2 and APP (Fotinopoulou et al., 2005; Kim et al., 2008; Matsuda et al., 2005, 2008, 2009a,b). Thus, it will be interesting to address whether alterations of this BRI2 function causes memory loss in British dementia. In conclusion, we present here a genetically congruous mouse model of Familial British Dementia with memory deficits. Analysis of this model indicates that amyloid deposition and tangles formation may follow rather than cause clinical dementia in FBD, contradicting the amyloid cascade hypothesis.

\section{References}

Akiyama H, Kondo H, Arai T, Ikeda K, Kato M, Iseki E, Schwab C, McGeer PL (2004) Expression of BRI, the normal precursor of the amyloid protein of familial British dementia, in human brain. Acta Neuropathol 107:53-58.

Bevins RA, Besheer J (2006) Object recognition in rats and mice: a one-trial nonmatching-to-sample learning task to study 'recognition memory.' Nat Protoc 1:1306-1311.

Bourtchuladze R, Frenguelli B, Blendy J, Cioffi D, Schutz G, Silva AJ (1994) Deficient long-term memory in mice with a targeted mutation of the cAMP-responsive element-binding protein. Cell 79:59-68.

Coomaraswamy J, Kilger E, Wölfing H, Schäfer C, Kaeser SA, WegenastBraun BM, Hefendehl JK, Wolburg H, Mazzella M, Ghiso J, Goedert M, Akiyama H, Garcia-Sierra F, Wolfer DP, Mathews PM, Jucker M (2010) Modeling familial Danish dementia in mice supports the concept of the amyloid hypothesis of Alzheimer's disease. Proc Natl Acad Sci U S A 107:7969-7974.

De Strooper B (2007) Loss-of-function presenilin mutations in Alzheimer disease. Talking Point on the role of presenilin mutations in Alzheimer disease. ЕMBO Rep 8:141-146.

Deleersnijder W, Hong G, Cortvrindt R, Poirier C, Tylzanowski P, Pittois K, Van Marck E, Merregaert J (1996) Isolation of markers for chondroosteogenic differentiation using cDNA library subtraction. Molecular cloning and characterization of a gene belonging to a novel multigene family of integral membrane proteins. J Biol Chem 271:19475-19482.

Diamond DM, Park CR, Heman KL, Rose GM (1999) Exposing rats to a predator impairs spatial working memory in the radial arm water maze. Hippocampus 9:542-552.

Fotinopoulou A, Tsachaki M, Vlavaki M, Poulopoulos A, Rostagno A, Frangione B, Ghiso J, Efthimiopoulos S (2005) BRI2 interacts with amyloid precursor protein (APP) and regulates amyloid beta (Abeta) production. J Biol Chem 280:30768-30772.

Garringer HJ, Murrell J, D’Adamio L, Ghetti B, Vidal R (2009) Modeling familial British and Danish dementia. Brain Struct Funct.

Giliberto L, Matsuda S, Vidal R, D'Adamio L (2009) Generation and initial characterization of FDD knock in mice. PLoS One 4:e7900.

Hardy J, Selkoe DJ (2002) The amyloid hypothesis of Alzheimer's disease: progress and problems on the road to therapeutics. Science 297:353-356.

Holton JL, Ghiso J, Lashley T, Rostagno A, Guerin CJ, Gibb G, Houlden H, Ayling H, Martinian L, Anderton BH, Wood NW, Vidal R, Plant G, Frangione B, Revesz T (2001) Regional distribution of amyloid-Bri deposition and its association with neurofibrillary degeneration in familial British dementia. Am J Pathol 158:515-526.

Holton JL, Lashley T, Ghiso J, Braendgaard H, Vidal R, Guerin CJ, Gibb G, Hanger DP, Rostagno A, Anderton BH, Strand C, Ayling H, Plant G, Frangione B, Bojsen-Møller M, Revesz T (2002) Familial Danish dementia: a novel form of cerebral amyloidosis associated with deposition of both amyloid-Dan and amyloid-beta. J Neuropathol Exp Neurol 61:254-267.

Kim J, Miller VM, Levites Y, West KJ, Zwizinski CW, Moore BD, Troendle FJ, Bann M, Verbeeck C, Price RW, Smithson L, Sonoda L, Wagg K, Rangachari V, Zou F, Younkin SG, Graff-Radford N, Dickson D, Rosenberry T, Golde TE (2008) BRI2 (ITM2b) inhibits Abeta deposition in vivo. J Neurosci 28:6030-6036.

LaFerla FM, Oddo S (2005) Alzheimer's disease: Abeta, tau and synaptic dysfunction. Trends Mol Med 11:170-176.

Matsuda S, Giliberto L, Matsuda Y, Davies P, McGowan E, Pickford F, Ghiso J, Frangione B, D’Adamio L (2005) The familial dementia BRI2 gene binds the Alzheimer gene amyloid-beta precursor protein and inhibits amyloid-beta production. J Biol Chem 280:28912-28916.

Matsuda S, Giliberto L, Matsuda Y, McGowan EM, D’Adamio L (2008) BRI2 inhibits amyloid beta-peptide precursor protein processing by interfering with the docking of secretases to the substrate. J Neurosci 28:8668-8676.

Matsuda S, Matsuda Y, D’Adamio L (2009a) BRI3 inhibits amyloid precursor protein processing in a mechanistically distinct manner from its homologue dementia gene BRI2. J Biol Chem 284:15815-15825.

Matsuda S, Matsuda Y, Snapp EL, D’Adamio L (2009b) Maturation of BRI2 generates a specific inhibitor that reduces APP processing at the plasma membrane and in endocytic vesicles. Neurobiol Aging. Advance online publication. doi:10.1371/journal.pone.0007900.

McGowan E, Eriksen J, Hutton M (2006) A decade of modeling Alzheimer's disease in transgenic mice. Trends Genet 22:281-289.

Phillips RG, LeDoux JE (1992) Differential contribution of amygdala and hippocampus to cued and contextual fear conditioning. Behav Neurosci 106:274-285.

Pittois K, Wauters J, Bossuyt P, Deleersnijder W, Merregaert J (1999) Genomic organization and chromosomal localization of the Itm2a gene. Mamm Genome 10:54-56.

Plant GT, Revesz T, Barnard RO, Harding AE, Gautier-Smith PC (1990) Familial cerebral amyloid angiopathy with nonneuritic amyloid plaque formation. Brain 113:721-747.

Price DL, Wong PC, Markowska AL, Lee MK, Thinakaren G, Cleveland DW, Sisodia SS, Borchelt DR (2000) The value of transgenic models for the study of neurodegenerative diseases. Ann N Y Acad Sci 920:179-191. 
Ramon y Cajal S (1911) Histologie du systeme nerveux. Paris: Maloine. English translation, 1995, Vol 1 (Swanson N, Swanson L). New York: Oxford University.

Rostagno A, Revesz T, Lashley T, Tomidokoro Y, Magnotti L, Braendgaard H, Plant G, Bojsen-Møller M, Holton J, Frangione B, Ghiso J (2002) Complement activation in chromosome 13 dementias. Similarities with Alzheimer's disease. J Biol Chem 277:49782-49790.

Sánchez-Pulido L, Devos D, Valencia A (2002) BRICHOS: a conserved domain in proteins associated with dementia, respiratory distress and cancer. Trends Biochem Sci 27:329-332.

Saura CA, Choi SY, Beglopoulos V, Malkani S, Zhang D, Shankaranarayana Rao BS, Chattarji S, Kelleher RJ 3rd, Kandel ER, Duff K, Kirkwood A, Shen J (2004) Loss of presenilin function causes impairments of memory and synaptic plasticity followed by age-dependent neurodegeneration. Neuron 42:23-36.

St George-Hyslop PH, Petit A (2005) Molecular biology and genetics of Alzheimer's disease. C R Biol 328:119-130.

Tamayev R, Matsuda S, Fa' M, Arancio O, D’Adamio L (2010) Danish Dementia mice suggest that loss of function and not the amyloid cascade causes synaptic plasticity and memory deficits. Proc Natl Acad Sci U S A, in press.

Trinchese F, Liu S, Battaglia F, Walter S, Mathews PM, Arancio O (2004) Progressive age-related development of Alzheimer-like pathology in APP/ PS1 mice. Ann Neurol 55:801-814.
Vidal R, Frangione B, Rostagno A, Mead S, Révész T, Plant G, Ghiso J (1999) A stop-codon mutation in the BRI gene associated with familial British dementia. Nature 399:776-781.

Vidal R, Revesz T, Rostagno A, Kim E, Holton JL, Bek T, Bojsen-Møller M, Braendgaard H, Plant G, Ghiso J, Frangione B (2000) A decamer duplication in the $3^{\prime}$ region of the BRI gene originates an amyloid peptide that is associated with dementia in a Danish kindred. Proc Natl Acad Sci U S A 97:4920-4925.

Vidal R, Calero M, Révész T, Plant G, Ghiso J, Frangione B (2001) Sequence, genomic structure and tissue expression of Human BRI3, a member of the BRI gene family. Gene 266:95-102.

Vidal R, Barbeito AG, Miravalle L, Ghetti B (2009) Cerebral amyloid angiopathy and parenchymal amyloid deposition in transgenic mice expressing the Danish mutant form of human BRI2. Brain Pathol 19:58-68.

Welsh K, Butters N, Hughes J, Mohs R, Heyman A (1991) Detection of abnormal memory decline in mild cases of Alzheimer's disease using CERAD neuropsychological measures. Arch Neurol 48:278-281.

Welsh KA, Butters N, Hughes JP, Mohs RC, Heyman A (1992) Detection and staging of dementia in Alzheimer's disease. Use of the neuropsychological measures developed for the Consortium to Establish a Registry for Alzheimer's Disease. Arch Neurol 49:448-452.

Zhang C, Wu B, Beglopoulos V, Wines-Samuelson M, Zhang D, Dragatsis I, Südhof TC, Shen J (2009) Presenilins are essential for regulating neurotransmitter release. Nature 460:632-636. 